\title{
Synthesis and Reactivity of the First Bis(crown ether) Enediyne
}

\author{
Burkhard König* and Heike Rïtters \\ Institut fiir Organische Chemie der Technischen Universităt Braunschweig, Hagenring 30. \\ D-38106 Braunschweig, Germany
}

\begin{abstract}
The synthesis of a new bis(crown ether)-enediyne 3 via palladium catalyzed coupling reactions is described. On treatment with sodium-hexafluorophosphate two cations are bound by the title compound 3; with potassium ions the sandwich complex 5 is formed. The thermal reactivity of the enediyne moiety towards cyclisation was investigated by differential scanning calorimetry, whereby the metal complexes showed an increased stability.
\end{abstract}

Synthetic and medicinal chemists have paid attention to enediyne antibiotics, such as calicheamicin 1 , esperamicin ${ }^{1}$ and dynemicin ${ }^{2}$, because of their potent anti-tumour properties and unique structures. These antibiotics manifest their biological activity in the form of DNA damage. The strand-sission is initiated by a 1,4dehydrobenzene biradical, the product of the thermally induced cyclisation ${ }^{3}$ of the enediyne functionality, which is present in each of the compounds. The cyclisation can occur at ambient temperature if it is facilitated by ring strain. The biological activity of the natural enediyne antibiotics is triggered by the bioreduction of adjacent functional groups 4 and by the change of conformation that is thereby induced. With the ultimate goal of developing functional analogues of the natural products for potential use in chemotherapy or as a tool for biotechnology, considerable attention has been given to the design of structurally simplified enediynes that retain their impressive DNA cleaving properties. Alternative methods of triggering biradical formation from enediyne systems have been developed, including $\mathrm{pH}$ dependent rearrangements 5 , redox based processes ${ }^{6}$ and photochemical strategies ${ }^{7}$.

The conformation of a molecule can be influenced by such non-covalent interactions as metal coordination $^{8}$ and hydrogen bonding ${ }^{9}$. We have investigated whether the reactivity of a simple acyclic enediyne functionality can be modified by the change in conformation due to complexation of adjacent crown ether moieties with different metal ions.

The palladium-catalyzed twofold coupling reaction of the parent enediyne $1^{10}$ system with two equivalents of $4^{\prime}$-iodobenzo-[15-crown-5] (2) ${ }^{11}$ yielded 1,6-bis-(4'-benzo-15-crown-5)-hex-3-en-1,5-diyne (3) ${ }^{12}$ in $65 \%$ under standard conditions. The compound is a slow solidifying oil with moderate stability. The $\mathbf{l}_{\mathbf{H}}$ NMR spectra $\left(\mathrm{CDCl}_{3}\right)$ consist of the aromatic signals at $\delta=6.92$ (singlet), 6.77 (doublet) and 7.07 (doublet), the typical crown ether pattern between $\delta=3.50-4.10$ and a sharp singlet for the olefinic protons at $\delta=6.02$. 
<smiles></smiles>

1<smiles>Ic1ccc2c(c1)OCCOCCOCCOCCO2</smiles>

2
$\mathrm{Pd}\left(\mathrm{PPh}_{3}\right)_{4}, \mathrm{CuI}$,

$\stackrel{n \text {-BuNH }{ }_{2} \text {, boromene }}{\longrightarrow}$

$65 \%$

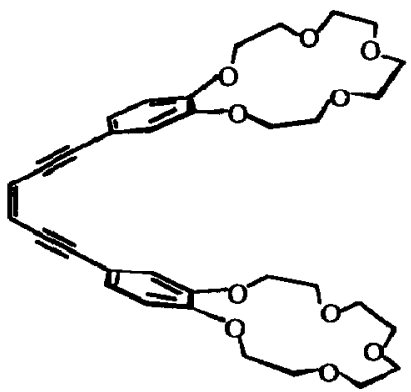

3

On treatment of 3 with excess $\mathrm{NaPF}_{6}$ or $\mathrm{NaClO}_{4}$ in acetonitrile at room temperature, complex 4 was formed quantitatively. By using $\mathrm{KPF}_{6}$ or $\mathrm{KClO}_{4}$ only one potassium ion was coordinated by the two crown ether moieties of 3. The FAB mass spectra and combustion analysis of 4 and 5 clearly indicate their stoichiometries. The formation of 2:1 sandwich-type complexes by bis(benzocrown ethers) with cations that exceed the size of the cavity is well documented in the literature ${ }^{13}$.

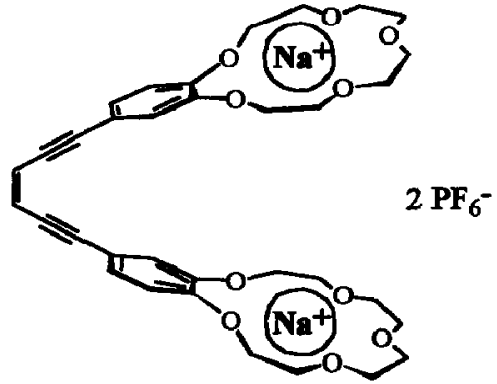

4

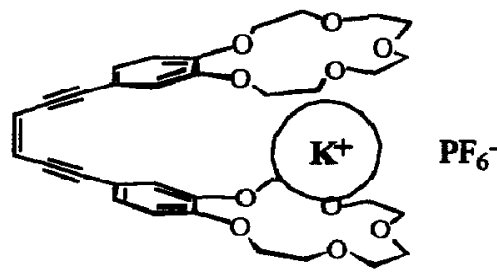

5

To ascertain the reactivity of the enediyne units on heating, the thermal properties of 3,4 and 5 were investigated by means of differential scanning calorimetry (DSC) ${ }^{14}$. At lower temperatures an endothermic process is observed corresponding to the melting points of the compounds $(3: 360 \mathrm{~K} ; 4,390 \mathrm{~K} ; 5: 420 \mathrm{~K})$. The more important feature, however, is a clear-cut exothermic dip which may reflect the cyclisation process beginning at $415 \mathrm{~K}$ for 3, at $430 \mathrm{~K}$ for 4 and at $442 \mathrm{~K}$ for 5 . All new crown ether compounds undergo an exothermic reaction at lower temperatures than the parent endiyne 1. By integration of the peak area the amount of energy evolved can be calculated. Similar values are obtained for all three compounds (3: $160 \mathrm{~kJ} / \mathrm{mol} ; 4: 155$ $\mathrm{KJ} / \mathrm{mol} ; 5: 162 \mathrm{KJ} / \mathrm{mol}$ ). The large values monitored in these measurements suggest a radical process ${ }^{15}$. The reaction may be initiated by the cyclisation process forming the biradical species which can then further polymerize with the enediyne moiety of unchanged material. On scanning the thermolyzed samples a second time no exothermic features are registered which indicates that an irreversible process has taken place. 
A rationale for the increased thermal stability of the metal complexes could be their presumable more rigid conformation. Electrostatic repulsion of the sodium ions in 4 and the intercalation of the large potassium ion in 5 could hinder the necessary approximation of the triple bonds for cyclisation.

The synthesis of enediyne derivatives which, through their non-covalent interactions with metal ions, show a decreased stability towards cyclisation may be envisioned. A diradical formation triggered by molecular recognition could lead to compounds with applications in cancer therapy and biotechnology. The development of synthetic receptors that show an initiated chemical response will be the subject of further research.

Acknowledgments: Financial support of the Fonds der Chemischen Industrie and generous gifts of chemicals by the Degussa AG are gratefully acknowledged. B. K. thanks the Fonds der Chemischen Industrie for a Liebig stipend. DSC measurements were kindly provided by Prof. Dr. C. Müller-Goymann and G. Hildebrandt. We thank Prof. Dr. H. Hopf for his continuing support.

\section{References and Notes}

1. (a) Nicolaou, K. C.; Groneberg, R. D.; Miyazaki, T.; Stylianides, N. A.; Schulze, T. I.; Stahl, W.; Schreiner, E. P.; Suzuki, T.; Iwabuchi, Y.; Smith, A. L. J. Am. Chem. Soc. 1993, 115, 7593 - 7611; (b) Nicolaou, K. C. Angew. Chem. 1993, 105, 1462 - 1471; (c) Golik, J.; Clardy, J.; Dubay, G.; Groenewold, G.; Kawakuch, H.; Konishi, M.; Krishinan, B.; Ohkuma, H.; Saitoh, K.; Doyle, T. W. J. Am. Chem. Soc. 1987, 109, 3461 - 3464; (d) Lee, M. D.; Dunne, T. S.; Siegel, M. M.; Chang, C. C.; Morton, G. O.; Borders, D. B. J. Am. Chem. Soc. 1987, 109, 3464 - 3468.

2. Semmelhack, M. F.; Gallagher, J.; Cohen, D. Tetrahedron Lett. 1990, 31, 1521 - 1522.

3. (a) Bergman, R. G. Acc. Chem. Res. 1973, 6, 25 - 31; (b) Bergman, R. G.; Jones, J. J. Am. Chem. Soc. 1972, 92, 660 - 661; (c) Lockhart, T. P.; Bergman, R. G.; Comita, P. B. J. Am. Chem. Soc. 1981, 103, 4082 - 4090; (d) Lockhart, T. P.; Bergman, R. G. J. Am. Chem. Soc. 1981, 103, 4091 - 4096.

4. (a) Suguira, Y.; Uesawa, Y.; Takahashi, Y.; Kuwahara, J.; Golik, J.; Doyle, T. W. Proc. Nat. Acad Sci. USA 1989, 86, 7672 - 7675; (b) Zein, N.; Poncin, M.; Nilakantan, R; Ellestad, G. A. Science 1989, 244, 697 - 699.

5. (a) Nicolaou, K. C.; Skokota, G.; Maligres, P.; Zuccarello, G.; Scheweiger, E. G.; Toshima, K.; Wendeborn, S. Angew. Chem. 1989, 101, 1255 - 1257; Angew. Chem. Int. Ed. Engl. 28, 1272 - 1275.

6. (a) Maier, M.; Brandstetter, T. Tetrahedron Lett. 1991, 32, 3679 - 3682; (b) Semmelhack, M. F.; Gallagher, J. J. Tetrahedron Lett. 1993, 34, 4121 - 4124; (c) Semmelhack, M. F.; Neu, T.; Foubelo, F. Tetrahedron Lett. 1992, 33, 3277 - 3279; Myers, A. G.; Dragovich, P. S. J. Am. Chem. Soc. 1992, 114, 5859 - 5860.

7. (a) Nuss, M. J.; Martin, M. M. Tetrahedron Lett. 1994, 35, 37 - 40; (b) Nicolaou, K. C.; Dai, W.; Wendeborn, S.; Smith, A. L.; Torisawa, Y.; Maligres, P.; Hwang, C.-K. Angew. Chem. 1991, 103, 1034 - 1038, Angew. Chem. Int. Ed. Engl. 1991, 30, 1032 - 1036.

8. (a) Beer, P. D.; Crane, C. G; Drew, M. G. B. J. Chem. Soc., Dalton Trans. 1991, 3235 - 3242; (b) Wada, F.; Wada, Y.; Goto, T.; Kikukawa, K.; Matsuda, T. Chem. Lett. 1980, 1189 - 1192. 
9. For recent examples, see: (a) Fan, E; VanArman, S. A; Kincaid, S.; Hamilton, A. D. J. Am. Chem. Soc. 1993, 115, 369 - 370; (b) Drain, C. M.; Fischer, R.; Nolen, E. G.; Lehn, J.-M. J. Chem. Sox., Chem. Commun. 1993, 243 - 245.

10. (a) Rato, G.; Linstrumelle, G. Tetrahedron Lett. 1981, 22, 315 - 318, (b) Linstrumelle, G.; Guillerm, D. Tetrahedron Lett. 1985, 26, 3811 - 3812, Vollhardt, K. P. C.; Winn, L. S. Tetrahedron Lett. 1985, 26, $709-712$.

11. Hyde, E. M.; Shaw, B. L.; Shepherd, I. J. Chem. Soc., Dalton Trans. 1978, 1696 - 1705.

12. (a) All new compounds were fully characterized and gave a satisfactory elemental analysis; (b) Selected spectroscopic data for $3:{ }^{1} \mathrm{H} \mathrm{NMR}\left(\mathrm{CDCl}_{3}, 400 \mathrm{MHz}\right) \delta 3.73-4.13(32 \mathrm{H}, \mathrm{m}), 6.02(2 \mathrm{H}, \mathrm{s}), 6.77(2 \mathrm{H}$, d, $3 J=8.3 \mathrm{~Hz}$ ), $6.92(2 \mathrm{H}, \mathrm{s}), 7.07(2 \mathrm{H}, \mathrm{d}, 3 J=8.3 \mathrm{~Hz}) ;{ }^{13} \mathrm{C} \mathrm{NMR}^{3}\left(\mathrm{CDCl}_{3}, 100 \mathrm{MHz}\right) \delta 68.30,68.89$, $69.96,70.65,86.65,97.78,112.92,115.69,116.78,119.24,125.28,148.26,149.56 ;$ MS (EI, $70 \mathrm{eV})$ $m / z 608\left(100, \mathrm{M}^{+}\right)$. - 4: 1H NMR (DMSO-[D] $\left.{ }_{6}, 400 \mathrm{MHz}\right) 83.60$ - 4.09 (32 H, M); 6.24 (2 H, s), 6.98 $(2 \mathrm{H}, \mathrm{d}, 3 J=8,3 \mathrm{~Hz}), 7.03(2 \mathrm{H}, \mathrm{d}, 4 J=1.9 \mathrm{~Hz}), 7.08(2 \mathrm{H}, \mathrm{dd}, 3 J=8.3 \mathrm{~Hz}, 4 J=1.9 \mathrm{~Hz}) ;{ }^{13} \mathrm{C} \mathrm{NMR}$ (DMSO-[D $\left.]_{6}, 100 \mathrm{MHz}\right) \delta 68.22,68.31,68.55,69.52,69.56,70.36,86.66,97.78,113.46,114.40$, $116.02,119.42,124.99,148.26,149.61$; MS (FAB $\left.{ }^{+}, \mathrm{NBA}\right) \mathrm{m} / z 799\left(38, \mathrm{M}^{+}\right.$- PF $), 154(100)$ - $5:{ }_{1} \mathrm{H}$ NMR (DMSO-[D]6, $400 \mathrm{MHz}) \delta 3.58$ - 3.78 (32 H, M); $6.24(2 \mathrm{H}, \mathrm{s}), 6.92\left(2 \mathrm{H}, \mathrm{d},{ }^{4} \mathrm{~J}=1.9 \mathrm{~Hz}\right), 6.97$ $\left(2 \mathrm{H}, \mathrm{d},{ }^{3} J=8.3 \mathrm{~Hz}\right.$ ), $\left.7.08\left(2 \mathrm{H} \text {, dd, } 3 J=8.3 \mathrm{~Hz},{ }^{4} J=1.9 \mathrm{~Hz} \text { ); }{ }^{13} \mathrm{C} \text { NMR (DMSO-[D] }\right]_{6}, 100 \mathrm{MHz}\right) \delta$ $67.07,67.19,67.44,68.48,68.53,69.18,69.34,87.43,98.35,112.83,114.47,116.28,120.31,124.50$, $147.48,148.95 ;$ MS (FAB $\left.{ }^{+}, \mathrm{NBA}\right) \mathrm{m} / 2647\left(100, \mathrm{M}^{+}-\mathrm{PF}_{6}\right)$.

13. (a) Truter, M. R. J. Chem. Soc, Perkin II 1972, 1818 - 1823; (b) van Remoortere, F. P. Inorg. Chem. 1974, 13, 2826 - 2834; (c) Beer, P. D., J. Chem. Soc., Chem. Comm. 1986, 1678 - 1680.

14. Elias, H.-G. Makromolekile, Bd. 1; Hüthig \& Wepf Verlag: Basel. 1990; pp. 817 - 820.

15. Grubbs, R. H.; Kratz, D. Chem. Ber. 1993, 126, 149 - 157.

(Received in Germany 11 February 1994; accepted 21 March 1994) 